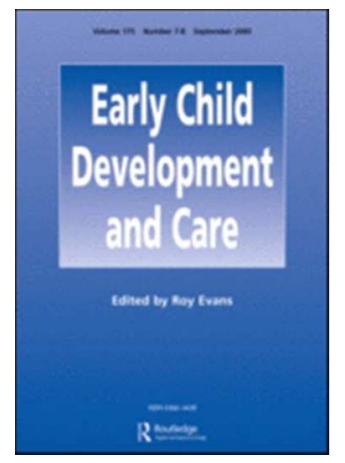

\title{
Parent-Practitioner Partnerships in Early Childhood Provision in England, Hungary and Kazakhstan: Similarities and Differences in Discourses.
}

\begin{tabular}{|r|l|}
\hline Journal: & Early Child Development and Care \\
\hline Manuscript ID & GECD-2017-0178.R2 \\
\hline Manuscript Type: & Special Issue Article \\
\hline Keywords: & $\begin{array}{l}\text { Parent-practitioner partnerships, Home-school links, Global monitoring, } \\
\text { International early childhood, Early childhood education and care, Early } \\
\text { childhood development }\end{array}$ \\
\hline \multicolumn{2}{|l}{} \\
\hline
\end{tabular}




\title{
Parent-Practitioner Partnerships in Early Childhood Provision in England, Hungary and Kazakhstan: Similarities and Differences in Discourses
}

\author{
Abstract \\ Whilst international policymakers have reached consensus on the importance of \\ investing in early childhood development and increasingly monitor that investment \\ using standardized measurement, the nature and rationale of early childhood \\ education and care (ECEC) provision remain diverse. In the context of that disparity, \\ this article explores an aspect of ECEC provision that is commonly recognised for its \\ potential to enhance young children's development and learning, yet for which \\ characteristics remain variable: partnerships between ECEC practitioners and \\ parents. The article reports and discusses results from a cross-cultural narrative study \\ that investigated the nature of such partnerships in three different countries: England, \\ Hungary and Kazakhstan. During focus group interviews, ECEC academics ( $\mathrm{n}=16)$ \\ discussed five themes that emerged from literature reviews. Findings indicate more \\ differences than similarities between the countries' narratives concerning ECEC \\ parent-practitioner partnerships, suggesting such partnerships may be an aspect of \\ ECEC provision for which a homogeneous approach and quality measure across \\ countries are not feasible.
}

Key Words: parent-practitioner partnerships; home-school links; global monitoring; international early childhood; early childhood education and care; early childhood development

\section{Introduction}

Globally, early childhood development has attracted increasing policy and investment in recent years (Lightfoot-Rueda \& Peach, 2015). However, there remains a lack of consensus concerning the nature and rationale for early childhood education and care (ECEC) provision (Kaga, Bennett, \& Moss, 2010). Within the context of that disjuncture, the position of parents and practitioners varies. For example, power relationships between parents and ECEC practitioners are often unequal (Cannella, 2002; Ministry of Education and Science of Republic of Kazakhstan [MESRK], 2012) and inconsistencies exist concerning the nature of relationships between parents and ECEC practitioners, within - and between - countries 
(Hujala, Turjab, Gaspar, Veisson, \& Waniganayake, 2009; Watson, 2012). Despite this divergent landscape, a trend has emerged for international standardized measures of educational outcomes (Moss, 2017; Rentzou, 2017; United Nations Educational, Scientific and Cultural Organization [UNESCO], 2016), including parent-practitioner partnership (Organisation for Economic Cooperation and Development [OECD], 2012). Nevertheless, although there is global agreement that positive relationships between parents and practitioners can benefit children's development and learning (Kernan, 2012; Moser et al., 2014), many ECEC practitioners do not work in partnership with parents (Taguma, Litjens, \& Makowiecki, 2012).

Because of the disparity between the potential of positive parent-practitioner partnerships and the variable nature of such partnerships (Hujala et al., 2009; Kernan, 2012; Watson, 2012), parent-practitioner partnership is a matter of quality (Taguma et al., 2012) that is often included as an aspect of ECEC teacher education. Taking these factors into account, when six ECEC academics based in England, Kazakhstan and Hungary engaged in scholarship visits to each other's universities in 2014-15, they planned a cross-cultural study of parent-practitioner partnership. The characteristics of those six researchers are set out in Table 1 and this article is a report of that study's design and findings. The article opens with a brief contextual overview, outlines the methodology, then presents and discusses findings. The study findings provide evidence for the argument that a homogeneous approach and standardized measurement of ECEC parent-practitioner partnerships may not be feasible or beneficial in England, Hungary and Kazakhstan.

\section{The Context for ECEC Parent-Practitioner Partnership and Cooperation in Three Countries}

In England, terminology concerning relationships between parents and ECEC practitioners includes 'partnership', 'involvement' and 'engagement' to describe various levels of equality (Goodall \& Montgomery, 2014). However, comparative terms used in Hungary and Kazakhstan translate most closely to 'co-operation' in English (Pálfi, 2010; Šteh \& Kalin, 2011; Zvereva, 2016).

\section{England}




\section{Hungary}

The Decree on the National Core Programme of Kindergarten Education (363/2012. [XII.17.]) [Core Program] was developed in 1996 and revised in 2011. It sets out ECEC principles and minimal requirements for Hungarian kindergartens. Since 2015, all children in Hungary aged 3-7 years have been required to attend kindergarten for four hours daily (Hungarian Government, 2012). The Core Program is a short framework determining common principles and aspects of Hungarian ECEC. Importantly, it does not have a 'curricular' requirement, giving Hungarian kindergartens unprecedented freedom to develop their own programs or apply and adopt existing kindergarten programs to suit their local educational contexts (Nagy Varga, Molnár, Pálfi, \& Szerepi, 2015). Nevertheless, Hungarian kindergartens are required to adopt a holistic view of children's development, characterised by unstructured play, unconditional love and child-centredness (Campbell-Barr, Georgeson, \& Nagy Varga, 2015; Hungarian Institute for Educational Research and Development [HIERD], 2012; Pukánszky, 2005). Because Hungarian kindergartens are poorly funded, they encourage most parents to raise funds and provide resources (Pálfi, 2006).

\section{Kazakhstan}

In Kazakhstan, the first nursery was founded in 1917 in Verny (Almaty) by Mouhlya, listener of Petrograd Froebel (Zhoumagozhina, 1973). When Kazakhstan gained independence in 
1991, about half the children younger than 7 years attended high quality preschool provision (United Nations Educational, Scientific and Cultural Organization [UNESCO], 2011).

However, by 1995, there were fewer kindergartens and the State Compulsory Standard for Early Childhood and Care was introduced to improve quality (MERSK, 2001). The Balapan Preschool Education Program (2010-2020) was intended to achieve 100\% pre-school enrolment for all 3-7-year-olds by 2020 (MESRK, 2010). Key kindergarten programs include Karlygash for 4-5 years, ZerekBala for 3-5 years and Algashky Kadam for 1-3 years (MESRK, 2007c, 2009a, 2009b).

\section{The Research Design}

The Study Focus

The study addressed the research question: 'What do academics and literature reveal about the similarities and differences concerning parent-practitioner partnerships in ECEC provision in England, Hungary and Kazakhstan?' It had two objectives: (1) To review literature, policy and research concerning parent-practitioner partnership in ECEC provision in England, Hungary and Kazakhstan and (2) To capture similarities and differences in ECEC academics' perspectives on issues arising from the review of literature, policy and research concerning parent-practitioner partnership in ECEC provision in England, Hungary and Kazakhstan.

\section{The Research Team}

The research team comprised six ECEC academics: two from each country (Table 1). Academics produce knowledge and teach in higher education (Kenny, 2017); they are in a 'unique position of privilege' to construct, accredit and challenge knowledge and systems (Farnum, 2014, p. 4). Additionally, the research team shared certain other characteristics (Table 1): all were ECEC academics and $83 \%$ were female; $83 \%$ were parents and had previously been ECEC practitioners so brought 'practical wisdom' (Goodfellow, 2003, p.9). The researchers were 'relative insiders' concerning ECEC parent-practitioner partnerships in their own countries (Griffiths, 1998, p.137), meaning they were knowledgeable about ECEC parent-practitioner partnerships, yet were professionally distant from such partnerships. Before the study began, all six researchers were also 'insider-outsiders': they knew about 
ECEC parent-practitioner partnerships in their own countries but not the other study countries (Griffiths, 1998, pp.138-139).

\section{Table 1 about here}

\section{Methodology}

The study was interpretive and adopted narrative research (Mitchell \& Egudo, 2003; Walsham, 1993). The research design secured rigour by examining findings across the three countries and by adopting analyst triangulation, since all six researchers analysed the data (Patton, 2002). The study comprised two phases: scoping reviews and focus group interviews.

For Phase One, a scoping review was conducted in each country concerning ECEC parent-practitioner partnerships. The reviews followed an established protocol (Civil Service, 2014) that grounded the study in the ECEC field and provided a text-based narrative for establishing patterns in data across the three countries (Rozas \& Klein, 2010). Researchers in each country selected two key words that aligned with the research question appropriately for their own country. They also identified up to three bibliographic databases that, as subject experts, they considered appropriate for the study in their countries. In England, Taylor and Francis and EbscoHost databases were used, with key words 'parent partnership' and 'parental involvement'. The Hungarian researchers used 'Académiai Adattár' (Academic Database), 'Matarka' and 'Debreceni Egyetem Egyetemi és Nemzeti Könyvtár' (University of Debrecen University and National Library) databases and key words 'kapcsolat szülökkel' ('parent partnership') and 'együttmüködés a szülökkel' ('cooperation with families'). In Kazakhstan, the National Centre for Research and Technical Information and Republican Research Pedagogical Library were main sources. The Kazakh team applied key words in Kazakh and Russian, using ‘Ата-аналар ынтымақтастығы’ (Kazakh) and 'Сотрудничество родителей' (Russian) ('parent cooperation') and ‘Ата-аналарды тарту’ (Kazakh) and 'Вовлечение родителей' (Russian) ('parental involvement'). Searches were limited to literature published in the past fifty years. The researchers refined their searches further with the terms 'early childhood education and care' and their country name in their own languages. The researchers then took the first 100 sources in each country and screened titles, abstracts and contents pages to ascertain their relevance to the research question and objectives. This protocol allowed identification of useful sources (Civil Service, 2014).

Phase One Analysis 
The protocol also allowed for thematic analysis, conducted by the six researchers sharing their perspectives and reaching agreement concerning the meanings in the data (Patton, 2002). An initial level of coding elicited themes from the selected sources in individual countries' literature, then a second level of coding established themes that were common to all three countries, providing a new 'overview of the state of knowledge' on ECEC parentpractitioner partnership across the three countries (Ling Pan \& Lopez, 2008, p.1). Hungarian and Kazakh reviews and coding were translated into English by researchers. Phase One themes from the three countries' data informed questions for Phase Two: three semistructured focus group interviews concerning parent-practitioner partnerships, undertaken with English, Hungarian and Kazakh ECEC academics in their own countries (McLafferty, 2004). The focus group questions were set in English, then translated into Hungarian and Kazakh:

(1) Where are we currently in our country regarding parental choice in ECEC provision?

(2) What is the balance of power in parent-practitioner partnership in ECEC provision?

(3) What do we think about the relationship between parent-practitioner partnership and the current school starting age in our country?

(4) What do we understand about the culture/s of parent-practitioner links in ECEC provision in our country?

(5) What is the role of early childhood provision and parenting in preparing children for formal schooling?

\section{Participants}

In this study, participants were only introduced in Phase Two, as Phase One was nonempirical. For Phase Two focus groups, purposive sampling secured 16 participants who presented with a range of characteristics (Table 2) but were selected according to certain criteria. They were ECEC academics in the researchers' universities, so were knowledgeable about the ECEC field and had established relationships with others in their groups, affording authentic narratives through habituation (Table 2). Interviews were recorded and transcribed; Hungarian and Kazakh transcriptions were translated into English. 
Table 2 about here

\section{Phase Two Analysis}

Thematic analysis of focus group data was conducted; first within individual countries, then across all datasets, securing rigour through analyst triangulation (Patton, 2002). To further enhance rigour, inter-rater reliability was applied: researchers identified and cross-referenced themes in focus group transcript sections within country and across countries (Armstrong, Gosling, Weinman, \& Marteau, 1997).

\section{Ethics}

Ethical considerations were made in respect of the empirical and non-empirical phases of the study and these were appropriate to the countries where data were collected. Ethical procedures in England and Kazakhstan followed the British Educational Research Association [BERA] guidelines (2011). A new 'Code of Ethics for Conducting Research in Education' was informed by BERA guidelines (2011) but published in Kazakhstan after data collection (Nazarbayev Intellectual Schools [NIS] Autonomous Educational Organisation [AEO], 2015). Hungary's Ethics Code of the Hungarian Academy of Sciences (Hungarian Academy of Sciences, 2010) guided ethical conduct of Hungarian elements.

\section{Phase One Findings}

Initial literature screening resulted in 565,828 sources in England, 948,095 in Hungary and 160,334 in Kazakhstan, of which 73,069 were in Kazakh and 87,265 in Russian. Five key themes emerged from the Phase One analysis process indicated above (Table 3 ) and indicative points from the literature concerning each of the five themes are presented below.

Table 3 about here

\section{Review Theme 1: Parental choice in ECEC provision}


Policies and practices in parental choice of ECEC provision are not aligned. In England, the 1988 Education Act (HMG, 1988) positioned parents as consumers, yet in practice, English parents have little choice regarding ECEC provision. Only $20 \%$ of pre-school settings in England are 'high quality' settings (Brind et al., 2014, p. 25) with middle class parents most likely to exercise choice (Ball, 2003). Equally, although Hungarian and Kazakh policies state that parents can choose their child's kindergartens, in practice Hungarian and Kazakh parents also tend to have limited choice, with location being the greatest influence in both countries (Teszenyi \& Hevey, 2015; Török, 2005; Government of the Republic of Kazakhstan [GRK], 2014).

\section{Review Theme 2: Power imbalances in parent-practitioner partnerships}

England's neo-liberal policies empower practitioners and parents variably: though parents are framed as consumers (Hursh, 2005), practitioners must encourage parents to 'schoolify' the home (DfE, 2017; McDowall Clark, 2016) and educators often find it difficult to forge equal relationships with parents (Schneider, Avis, \& Leighton, 2007). Hornby (2000) reveals power imbalances in English parent-practitioner partnerships, and terminology mirrors those inequities (Goodall \& Montgomery, 2014). In Hungary, families' needs have been increasingly considered by kindergarten educators (Korintus, Villányi, Mátay, \& Badics, 2004). However, whilst Kazakh practitioners have been required to work more with parents to support children's learning (Iskakova, 2008; MESRK, 2001), policy has only recently attempted to equalise parent-practitioner partnerships (MESRK, 2009c, 2012).

\section{Review Theme 3: School starting ages}

At five years, the school starting age in England is earlier than most countries (OECD, 2017), but many children enter school in England in the autumn of the school year of their fifth birthday. This is a highly contested situation (McDowall Clark, 2016), not least because summer-born children tend to achieve less well than their peers in English schools (Crawford, Dearden, \& Greaves, 2013). In Hungary, however, compulsory school age is a child's sixth birthday, and children can stay at kindergarten until seven years (HIERD, 2012). Equally, Hungary's Act CXC of 2011 on Public Education lowered the compulsory kindergarten starting age from five to three years to reduce socio-cultural and socio-economic disadvantage (Molnár, Pálfi, Szerep, \& Varga, 2015). Similarly, in Kazakhstan children may 


\section{Review Theme 4: Culture of parent-practitioner links in ECEC provision}

ECEC practitioners in England have engaged with parents for many years (Read, 2015). The Pre-School Playgroup Association was founded by a parent in 1961 (Whitbread, 1972) and in 1967, the Plowden Report advocated home-school links for all primary schools (Central Advisory Council for Education, 1967). Since 1999, practitioners in England have been required to enhance 'parenting aspiration and skills' for children aged 0-5 years of low socioeconomic status (SES) (Read, 2015, p.52), but sometimes this leads to vulnerable families mistrusting practitioners (Royston \& Rodrigues, 2013). Since Hungary's independence in 1990, a culture of cooperation with parents has developed, characterised by meetings between pedagogues and parents before children start kindergarten and opportunities to discuss children's ECEC needs together. Parents join their children for their initial days of kindergarten, and may attend activity afternoons, health education programs, trips and parties with pedagogues, children and other families: fathers are strongly encouraged (Bakonyi, 2016; Herczog, 2008; Korintus et al., 2004). In Kazakhstan, however, parents tend to be regarded as subordinate to practitioners (Iskakova, 2008). Barriers to interactions between families and ECEC settings include 'lack of time', 'reluctance to cooperate'; and parents' lack of trust in practitioners (Danilina, 2000; Tonkova \& Veretennikova, 2012).

\section{Review Theme 5: The role of ECEC provision in preparing children for formal schooling.}

Active parental interest impacts positively on children's outcomes (Desforges \& Abouchaar, 2003; Harris \& Goodall, 2007), so in England, many programmes engage parents as coteachers, including PEEP (Evangelou et al., 2005), PEAL (Wheeler \& Connor, 2009) and REAL (Nutbrown, Hannon, \& Morgan, 2005). However, the English statutory requirement that practitioners must engage parents to prepare children for academic learning is highly contested, particularly given England's young school starting age (DfE, 2017; McDowall Clark, 2016). Conversely, the Hungarian Core Program removed any requirement for kindergartens to prepare children for school (Pálfi, 2004): it confirmed the specific 'nurturing' role Hungarian kindergartens assume, and articulated new expectations of schools 
(HIERD, 2012). In Kazakhstan, all children aged 5-6 years must attend one year of preparation for formal schooling, usually funded by government (GRK, 1999; UNESCO, 2011). Most Kazakh parents believe that academic learning is crucial once their children start school but many do not support younger children's learning at home (GRK, 2015) because they regard this as the ECEC settings' role, and they prioritise their own paid work (Epifanova, 2015).

\section{Phase Two Findings}

Thirteen themes emerged from the focus group data, of which four were common to all three countries:

(i) 'Interactions and Responses'

(ii) 'Time and Transitions'

(iii) 'Social Impacts and Social Structures' and

(iv) 'Policy, Standards and Frameworks'.

One theme was shared by only England and Hungary: 'Values and Valuing People' and four themes were only shared by England and Kazakhstan: 'Money', 'Place/Location', 'Decision Making' and 'Comparative Education'. Additionally, only Hungary's data included the themes 'Disadvantaging people', 'Innovation' and 'Functions of the Kindergarten', while 'Curriculum' only emerged from the Kazakh data. Within the four common themes, 36 subthemes presented, of which ten were shared by all three countries. Given the expanse of the data, it is only possible to include a selected sample in this article. Data for the four common themes are presented below because they indicate that even where similar themes exist across all three countries, differences exist within their sub-themes.

\section{(i) Interactions and Responses}

Within this theme, English data featured five sub-themes:

- Personal feelings

- Relationships

- Community

- Recommendations and friends

- Individualised support for parents.

English academics believed that personal feelings determine parents' childcare choices and parents value relationships in ECEC: a 'nice friendly nursery' where practitioners 'cuddle' 
children. They said parental childcare choices depend on social class, beliefs, personal experiences, resources, individual needs and '...the cultural value of community' and thought parents tend to rely on 'word of mouth' when choosing a setting. They also suggested that valuing each parent as 'unique' may support parent-practitioner partnerships, particularly with parents who '...did not have a nice time at school'.

Sub-themes in Hungarian academics' narratives were:

- Keeping contact

- Engaging with families of low SES

- Professional love.

They noted that Hungarian parents and ECEC practitioners tend to combine established and new ways to make contact: '...dialogue between pedagogues, home visits, parents 'evening'. They said that Hungarian, '...pedagogues are not really able to address the parents individually... there are better ways' than parent-practitioner group meetings and they advocated that engagements with families of low SES should feature: '...empathy: understanding the situation and difficulties of parenthood'. They also emphasised that Hungarian parents expect pedagogues to love each child and be 'people to whom the child has a close emotional attachment'.

Kazakh academics' narratives featured:

- Activities to support Interaction

- Parent education

- Culture of family-setting relationships

- Teachers modelling communication.

They noted that practitioners involve and 'educate parents' using innovative and traditional methods but they found the culture of family-setting relationships problematic: 'Some parents ignore (the) practitioner's greeting and leave in rush. It's just very rude... when I visit setting meetings...only 4-5 parents attend'. Kazakh academics advocated less formality to equalise parent-practitioner partnerships: '...individual conferences...to discuss with family sensitive issues'. They also thought practitioners should model communication with children, for example by drawing '...parents' attention to children's achievements through compliments about their children'.

(ii) Time and Transitions 
For this theme, all three countries' narratives included the sub-theme 'Transitions'. 'Time' only presented in the English data, but it was prominent.

English academics believed parents' childcare choices were influenced by working hours and travel time between their home and setting. They also thought parents become more interested in their children's learning at specific transition points, especially the final nursery year: '... the focus would really be on ... their achievement and... are they going to be ready for school, particularly academically'. Nevertheless, they thought parents' poor attendance at school curriculum information evenings in England demonstrated their weakening interest once children enter school and they were concerned that many children aged 4-5 years in English schools experience exhaustion and 'emotional distress'.

Hungarian academics suggested that Hungarian parents are more strongly influenced by other parents than a kindergarten's pedagogical program when choosing a kindergarten: '(They) talk with other parents: previous ones, parents of near-school age kids should welcome the new ones and talk about the kindergarten, their experiences'. They also noted that Hungarian children moving to formal schooling at 6 or 7 years old experience stress, which pressurises kindergarten pedagogues: ' ...there is this need from parents and as a top down model, we also have this pressure from the school, the kind of things kindergartens should do to prepare children for school', (so that they) 'use worksheets with children' to keep children on roll.

Kazakh academics defined 'school readiness' as children's 'good understanding of reading, writing and arithmetic'. They noted that parents become '...more engaged in the learning process when their children start school' and although they said Kazakh parents tend to be more anxious than their children about starting school, they indicated that parents' anxiety sometimes transfers to children. They suggested Kazakh parents are mainly concerned about their children's academic success at school: 'Parents help children to adjust to school therefore they are very closely linked with the teacher. This might be homework and support from teacher in doing homework'.

\section{(iii) Social Impacts and Social Structures}

For this theme, six sub-themes emerged from English academics' narratives:

- Universal (ECEC) services 
- Class

- Power

- Accountability

- Socio-cultural constructs of teachers and teaching

- Ethos.

They wanted universal (ECEC) services for children in England to secure equal opportunities: '...we shouldn't have private education' and they linked class to money and weak social mobility, suggesting that middle-class English parents are likely to say: 'I don't want my child mixing with' less affluent children and if '...you've got the means to get your child to that good setting you can'. English academics also observed that: '...lower socioeconomic class (parents)...feel quite threatened by the power they perceive practitioners have' and they discussed accountability, arguing parent-teacher relationships had become 'more officious', with teachers '...answerable to everything' in England. They also deliberated socio-cultural constructions of teaching in England, saying '...everybody has got an opinion on teaching, everybody thinks they can (teach)'. Finally, in respect of this theme, English academics suggested that some parents reject partnership: '...they don't want ...that level of interaction; it is classed as unprofessional' and they highlighted that in parentpractitioner partnerships: 'the balance of power depends on the ethos where you work'.

Hungarian academics identified three sub-themes for this theme:

- Changes in ECEC

- Increased cooperation

- Innovative links with parents.

They said that since independence, Hungary's 'ideologically rigid, institutionalised', 'authoritarian' Soviet-style educational system has become a more democratic, child-centred model. They thought their country's new market economy and higher maternal employment have transformed parents' roles and parent-practitioner relationships: '...in recent years, fathers also appear with mothers in the kindergarten'. They also highlighted increased parent-practitioner co-operation: '... when kindergartens have less and less money, (they) have to pay attention to fathers because they can physically do more for them'. Hungarian academics suggested more grandparents now '...come into the kindergarten and carry out ... activity... with the children' and they discussed the increased co-operation between different agencies which '... have a significant role in the life of the society', including 
visitors who introduce children to local: '...customs and celebrations, (so) life becomes more interesting and colourful for children'. Hungarian academics noted '...the relationship of the kindergarten with the local community is of great significance' and debated ways their kindergartens continually develop: '...new and innovative ways of keeping in contact with families'.

Kazakh academics highlighted the sub-themes:

- Workforce development challenges

- Structural quality and accessibility of pre-school provision.

They observed that ECEC workforce development challenges in Kazakhstan have caused imbalance in practitioner-parent partnerships because 'The age of highly-qualified staff is 50 and...not showing openness to new ideas and developments. Employability for newly qualified kindergarten practitioners is difficult because the salaries are very low'. Kazakh academics also suggested that structural quality and accessibility of pre-school provision compromise equal opportunities: 'Today, the provision of nursery is (only) $85 \%$.' They were concerned by diminishing quality: '... more than 35 children are taught by a practitioner at (a) government-owned nursery. However middle-class parents can afford to choose private nurseries where (the) practitioner works with 10 children.' One academic remarked:

'...not all children attend a nursery (so) children start school with different level of skills. Primary teacher has a task to adjust these skills...parents and teachers have different approaches to the schoolification. Parents believe that the reading and writing skills are enough to start school and a key to successful learning.'

Nevertheless, Kazakh academics noted: '...today nurseries offer many extra activities. For instance, dance and sport activities which are helpful to develop children's physical abilities. Also, the diversity of language classes.' They also indicted that 'In 2020...100\% of children (in Kazakhstan) should be provided with ECEC'.

\section{(iv) Policy, Standards and Frameworks}

For this theme, English academics's sub-themes included:

- Process Quality

- Imposition of school agenda on ECEC

- Professionalisation of care 
- Policy

- Office for Standards in Education (Ofsted), the English education regulator.

English academics thought education discourse in England focuses on 'standards'. One said: '...everywhere should be of a high quality', but another questioned what constitutes high quality: '(What does) really good input look like? Because people are still trying to decide.' Another English academic suggested: 'You need to have a teacher with that confidence to be able to move away slightly from ... the curriculum', to respond to children's needs. English academics thought a schooling agenda is imposed on ECEC in England: '...we're looking at these GCSE results (examinations at 16 years) which are not as brilliant as we want them to be...instead of actually looking and saying what are we doing at the bottom'. English academics regarded ECEC professionalisation as 'putting the children first', which they linked to trust, characterised by 'transparency' and 'building relationships'. They expressed concern that increasing market forces have led to assumptions that image equates to professionalism: for example, some English settings require early years teachers to wear office suits. English academics highlighted policy as '...the biggest influence ... in an early years setting' but noted inconsistencies concerning regulation: whilst '...everything (practitioners) were doing for parental involvement was down to Ofsted', '... when you get an inspection, $(O f$ sted)... wouldn't ask what your results are in parental engagement'.

Hungarian sub-themes within this theme were:

- New legislation

- Localism

- Individualism.

Hungarian academics noted that Hungary's Act CXC of 2011 on Public Education has meant '...kindergarten is compulsory from the age of 3 and the statutory Core Program prescribes three functions for kindergartens: '1. The safe-guarding function; 2. The nurturing/developing function and the 3. the social function'. They also observed that the Act $\mathrm{CXC}$ states that '...the kindergarten has a role to complement the role of the family to reduce disadvantage (and build) a strong relationship between parents and pedagogues'. Discussing localism, Hungarian academics said: ' ... the (national) programme does not specify particular ways for maintaining partnerships or the content of these partnerships. These are left to be developed locally'. They commented that the kindergarten pedagogue's role focuses on individual needs: '...the most important thing is the personality of the pedagogue, followed closely by the personality of the assistant, to whom children are emotionally attached'. 
Kazakh academics focused on only one sub-theme within this theme: the State Compulsory Education Standard in ECEC (MERSK, 2001, 2007a, 2008, 2009c, 2012). They discussed how its successive iterations show how parental involvement has developed in Kazakhstan but they questioned the onus this has placed on ECEC practitioners (MESRK, 2001): '...we, experts and practitioners...need to establish two-directional interaction recommendations or strategies'. They said that despite government focus on family values, 'Due to busy working days, parents often are not able to visit nurseries and events which are organized by children and practitioners'. They also observed that while MESRK (2007a, 2008) highlighted the importance of parental involvement it did not suggest practical approaches: 'Unfortunately, 40-50\% EYs settings face difficulties in working with parents and in this case parent-practitioner interaction happens only in reports'. However, Kazakh academics noted that a later version included information for parents and 'mechanisms of working with parents which are actively used in early years settings' (MESRK, 2009c). They said new ideas for parent-practitioner partnership have followed Kazakhstan's engagement with international models of education (MESRK, 2012, 2014): 'We may adopt this experience of interacting from British ECEC...for example when parents drop in children they are allowed to enter the room and stay with their child'.

\section{Discussion}

The findings presented above demonstrate that the study objectives were met: literature, policy and research were reviewed concerning parent-practitioner partnership in ECEC provision in England, Hungary and Kazakhstan and similarities and differences in ECEC academics' perspectives were captured on issues arising from that review. This section responds to the overarching research question by discussing what the data reveal about similarities and differences concerning parent-practitioner partnerships in ECEC provision in England, Hungary and Kazakhstan. Mirroring the presentation of findings, this section is structured according to the four themes that are common to all three countries.

\section{(i) Interactions and Responses}

There is limited connectivity across 'Interactions and Responses' sub-themes, which are all concerned with positive relationships in ECEC, yet English academics suggested that parents value 'relationships' (Cottle \& Alexander, 2014), while the Hungarian literature aligns with family friendly ways of 'keeping contact' that Hungarian academics highlighted in this study: 


\section{(ii) Time and Transitions}

Academics from all three countries alluded to 'Transitions', defined as 'an ongoing process of mutual adaptations by children, families and schools' (Petriwskyj, Thorpe, \& Tayler, 2005, p.56). Academics in each country suggested that practitioners and parents focus more on children's academic achievement as they move to school. In England, they said parents become anxious about the requirement that their children acquire literacy and mathematics skills at 4-5 years (MacDowall Clark, 2016), while in Hungary, despite policy to the contrary (HIERD, 2012), some kindergartens feel pressurised by parents to prepare children for school. In Kazakhstan, partnership between ECEC settings and schools increases alongside preparation and assessment for formal schooling at 5-6 years (GRK, 2015).

Only English academics introduced 'Time' as a sub-theme but they emphasised it strongly, noting that parents' working hours affect family time and childcare choices (Hunt, 2009). They also suggested that starting English primary school at 4-5 years old causes some children exhaustion and 'emotional distress' (Christensen, James, \& Jenks, 2000). Since 
insufficient sleep inhibits academic achievement, starting school young may be detrimental to the English government's performativity agenda (Ashworth, Hill, Karmiloff-Smith, \& Dimitriou, 2014; Roberts-Holmes \& Bradbury, 2016).

\section{(iii) Social Impacts and Social Structures}

Change was an underlying link within this theme. English academics advocated that ECEC in England should become a 'universal service', since the current model is fragmented, expensive and often inaccessible (Hillman \& Williams, 2015); equally, they were concerned that 'accountability' should not continue to dominate education in England (Roberts-Holmes \& Bradbury, 2016). Hungarian academics suggested 'changes in ECEC' in Hungary resulted from the introduction of a market economy, leading to increased maternal employment and more fathers and grandparents becoming involved (Korintus et al., 2004). Kazakh academics were troubled about inequalities caused by decreasing quality and disparities in ECEC provision, especially accessibility. However, they looked forward to $100 \%$ enrolment in early childhood education by 2020 (Iskakova \& Tajiyeva, 2012; MESRK, 2010, 2015, 2016). Narratives concerning 'socio-cultural constructs of teachers and teaching' (England) and 'workforce development challenges' (Kazakhstan) were congruent but focused on different aspects: while English academics said many people in England problematise teachers and teaching (Ottesen, 2007), Kazakh academics were concerned about an aging workforce resistant to change, low salaries and recruitment challenges (MESRK, 2015).

The sub-theme 'ethos' that English academics identified aligned with 'kindergartens' innovative links with parents and increased cooperation' identified by Hungarian academics. English academics said variable ethos across settings means differences in parent-practitioner relationships (Whalley, 2007). Hungarian academics observed that kindergartens are more child-centred since the country gained independence. They cooperate with other agencies and families in active, innovative ways, although not all fully prioritise children's interests (Vágó, 2002). However, 'class' and 'power' featured exclusively in the English academics' narratives where social mobility is weak, and education is not helping (Ball, 2003; Social Mobility Commission, 2016).

\section{(iv) Policy, Standards and Frameworks}

Whilst four of this theme's sub-themes map across two countries, none connect across all three countries. English academics thought 'policy' influences English ECEC (DfE, 2017; 


\section{Similarities and Differences: What do they mean?}

In seeking a response to the research question: 'What do academics and literature reveal about the similarities and differences concerning parent-practitioner partnerships in ECEC provision in England, Hungary and Kazakhstan?', establishing patterns in the data was important, given that it was a narrative study (Rozas \& Klein, 2010; Walsham, 1993). Thirteen themes emerged from the focus group data, of which only four were common to all three countries, whereas five themes were shared by two countries, and four appeared in only one country's data. From the four common themes, 36 sub-themes emerged, of which only ten were shared by all three countries, while fourteen mapped across two countries and twelve appeared in only one country's data. These data revealed some similarities across themes and sub-themes, and by doing so indicated some shared understandings across the three participating countries regarding ECEC parent-practitioner partnerships. However, the data revealed many more differences than similarities between the three study countries concerning ECEC parent-practitioner partnerships. The findings therefore suggest that a homogeneous approach to parent-practitioner partnerships in ECEC provision across England, Hungary and Kazakhstan is unlikely to be feasible. Without a shared approach, criteria for standardized measurement of such partnerships would be difficult to establish. Equally, whilst factors that currently characterise ECEC parent-practitioner partnerships in England, Hungary and Kazakhstan may not always be optimal, they have relevance for parents and ECEC practitioners in each country, making them meaningful for those involved. 
This finding suggests that attempting a homogeneous approach and standardized measurement may detract from valued features of relationships between parents and ECEC practitioners in the three countries.

\section{Study Limitations}

The study had some limitations. Firstly, its design included a relatively small number of participants from only three universities in three countries. However, its small scale and interpretive quality allowed rich narrative data to emerge. Whilst the study findings cannot be assumed to be generalisable, they are indicative and could provide a basis for a larger crosscultural study to explore ECEC parent-practitioner partnerships. Some may argue that a second limitation was the subjective 'insider' nature of the researchers (Griffiths, 1998, pp.137-9): they all had existing working relationships with participants in their own countries, and they were all familiar with the international ECEC field and ECEC parentpractitioner partnerships in their own countries. However, the counter argument is that subjectivity is advantageous for interpretive studies (Armstrong et al., 1997). The researchers' 'insider' knowledge enabled them to identify appropriate key words and databases for the literature review, to ask questions that elicited useful, relevant data, to use habituation to elicit authentic narratives, to value participants' multiple perspectives and to understand, check and attribute meanings in the data. The use of thematic analysis for both study phases required researchers to seek patterns (Rozas \& Klein, 2010; Walsham, 1993), a bias that potentially presented a third limitation; yet many more differences than similarities emerged from the datasets. The practical challenges of working across countries presented a fourth limitation: collating and analysing data required careful coordination because the teams were geographically dispersed. Equally, translation was necessary but time consuming and presented interpretation concerns. Those concerns were addressed by researchers undertaking and checking translation themselves: as educators, they conducted the task in a socially responsible way (Drugan \& Tipton, 2017) and the translation process added further opportunities to check understandings, mitigating the additional limitation of cultural dissonance between researchers and participants in the three study countries.

\section{Conclusion}




\section{References}

Alexander, T. (1997). Family learning: The foundation of effective education. London:

Demos

Armstrong, D., Gosling, A., Weinman, J., \& Marteau, T. (1997). The place of inter-rater reliability in qualitative research: An empirical study. Sociology, 31(3), 597-606.

Ashworth, A., Hill, C.M., Karmiloff-Smith, A., \& Dimitriou, D. (2014). Sleep enhances memory consolidation in children. Journal of Sleep Research, 23(3), 304-310.

Bakonyi A. (2014). Szülők és óvodapedagógusok együttmüködése, Fejlödés és fejlesztés az óvodában. Budapest: RAABE Kiadó.

Bakonyi, A. (2016). Az Óvodapedagógusok Nagykönyve. Budapest: Neteducatio.

Ball, S.J. (2003). Class strategies and the educational market: The middle classes and social advantage London: RoutledgeFalmer.

Brind, R., McGinigal, S., Lewis, J., \& Ghezelayagh, S., with Ransom, H. Robson, J., Street, C. ... Renton, Z. (2014). Childcare and early years providers survey 2013. London: Department for Education.

British Educational Research Association (2011). Revised ethical guidelines for educational research. London: British Educational Research Association. 
Campbell-Barr, V., Georgeson, J., \& Nagy Varga, A. (2015) Developing professional early childhood educators in England and Hungary: Where has all the love gone? European Education, 47(4), 311-330.

Cannella, G.S. (2002). Deconstructing early childhood education. New York: Peter Lang. Central Advisory Council for Education (1967). Children and their primary schools. London: Her Majesty's Stationery Office.

Christensen, P., James, A., \& Jenks, C. (2000). Home and movement: Children constructing family time. In S. Holloway, \& G. Valentine (Eds.) Children's Geographies: Playing, living, learning (pp. 139-155). Abingdon: Routledge.

Civil Service (2014, April 2nd). What is a Rapid Evidence Assessment? Retrieved from http://webarchive.nationalarchives.gov.uk/20140402163359/http://www.civilservice.gov.uk/n etworks/gsr/resources-and-guidance/rapid-evidence-assessment/what-is

Cottle, M., \& Alexander, E. (2014). Parent Partnership and 'Quality' Early Years Services: Practitioners' perspectives. European Early Childhood Education Research Journal, 22(5), 637-659.

Crawford, C., Dearden, L., \& Greaves, E. (2013). Identifying the drivers of month of birth differences in educational attainment. London: Institute for Fiscal Studies.

Crozier, G. (2012). British Educational Research Association: Researching parent-school relationship. Retrieved from: https://www.bera.ac.uk/wpcontent/uploads/2014/03/Researching-parent-school-relationships.pdf

Danilina, T. (2000). Contemporary issues of family and kindergarten interaction. Early Childhood Care, 1(2), 44-49.

Deliné Fráter K. (2010). A differenciáló pedagógia alapjai sajátosságai az óvodai nevelésben. Hajdúböszörmény: Debreceni Egyetem Gyermeknevelési és Felnőttképzési Kar. Department for Education (DfE) (2012). Statutory framework for the early years foundation stage. London: DfE.

Department for Education (DfE) (2015). Childcare bill: Policy statement. Retrieved from: https://www.gov.uk/government/uploads/system/uploads/attachment_data/file/482517/Childc are_Bill_Policy_Statement_12.03.2015.pdf

Department for Education (DfE) (2017). Statutory framework for the early years foundation stage. London: DfE.

Desforges, C., \& Abouchaar, A. (2003). The impact of parental involvement, parental support and family education on pupil achievement and adjustment: A literature review. Report Number 433. London: Department of Education and Skills. 
Drugan, J., \& Tipton, R. (2017). Translation, ethics and social responsibility. The Translator, 23(2), 119-125.

Epifanova, S. (2015). Features of interaction between pedagogues and parents in children's schoolification within EY settings. Volume of II International Research Conference:

Innovative pedagogical strategies. Kazan.

Evangelou, M., Brooks, G., Smith, S., Jennings, D., \& Roberts, F. (2005). The birth to school study: A longitudinal evaluation of the peers early education partnership (PEEP) 1998-2005. London, DfES.

Farnum, R. (2014). Contesting or creating hegemony? A critique of the London Water Research Group considering academic hegemony and traps in social justice research. Concept Paper prepared for HH7. Retrieved from: https://www.uea.ac.uk/documents/40159/5624523/Contesting+or+Creating+Hegemony++LWRG+Critique.pdf/e94acbb0-f28c-4b84-8819-501d91f1433a

Goodall, J., \& Montgomery, C. (2014). Parental involvement to parental engagement: A continuum. Educational Review, 66(4), 399-410.

Goodfellow, J. (2003). Practical wisdom in professional practice: The person in the process. Contemporary Issues in the Early Years, 4(1), 48-63.

Government of Republic of Kazakhstan (GRK) (1999). On issues of mandatory pre-primary education of children (Resolution of the Government of the Republic of Kazakhstan dated November 22, 1999, No. 1762). Astana: GRK

Government of Republic of Kazakhstan (GRK) (2014). Standard of state services children's enrolment to ECEC: Government decree of Republic of Kazakhstan N633, June 92014.

Astana: Ministry of Justice of Republic of Kazakhstan. Retrieved from:

http://adilet.zan.kz/rus/docs/P1400000633

Government of Republic of Kazakhstan (GRK) (2015). National report on education development system of Republic of Kazakhstan (result of 2014) Astana: GRK. Grenier, J. (2017). Successful early years Ofsted inspections. London: Sage. Griffiths, M. (1998). Educational research for social justice. Buckingham: Open University Press.

Harris, A., \& Goodall, J. (2007). Engaging parents in raising achievement: Do parents know they matter? London: Department for Children, Schools and Families. Her Majesty's Government (1988). Education reform act. London: HMSO. Her Majesty's Government (2006). The childcare act. London: The Stationery Office. 
Herczog M. (2008). A kora gyermekkori fejlődés elősegítése. In: K. Fazekas, J. Köllő, \& J. Varga (Eds.) Zöld könyv a magyar közoktatás megújításáért (pp.33-52). Budapest: ECOSTAT.

Hillman, J., \& Williams, T. (2015). Early years education and childcare. London: Nuffield Foundation.

Hobart, C., \& Frankel J. (2014). A practical guide to working with parents. Oxford: Oxford University Press.

Hornby, G. (2000). Improving parental involvement. London and New York: Cassell.

Hujala, E., Turjab, L., Gaspar, M.F., Veisson, M., \& Waniganayake, M. (2009). Perspectives of early childhood teachers on parent-teacher partnerships in five European countries.

European Early Childhood Education Research Journal, 17(1), 57-76.

Hungarian Academy of Sciences (HAS) (2010). Ethics code of the Hungarian Academy of Sciences. Budapest: Hungarian Academy of Sciences.

Hungarian Government (2012). The Decree on the National Core Programme of Kindergarten Education (363/2012. [XII.17.]). Retrieved from:

http://www.njt.hu/cgi bin/njt_doc.cgi?docid=157536.233760

Hungarian Institute for Educational Research and Development (HIERD) (Ed.) (2012). Early childhood education and care: Specificities of the Hungarian system. Budapest: Hungarian Institute for Educational Research and Development.

Hunt, S. (2009). Family Trends - British families since the 1950s. Retrieved from: http://www.familyandchildcaretrust.org/sites/default/files/files/Family\%20Trends $\% 20$ \%20British $\% 20$ families $\% 20$ since $\% 20$ the $\% 201950$ s.pdf

Hursh, D. (2005). Neo-liberalism, Markets and Accountability: Transforming education and undermining democracy in the United States and England. Policy Futures in Education, 3(1), 3-15.

Iskakova, A. (2008). Schoolification of children. Almaty: Areket-Print.

Iskakova, A., \& Tajiyeva, M. (2012). A comparative analysis of education programmes in preschool education of Kazakhstan. Volume of VIII International Research Conference, Bulgaria.

Jávorné Kolozsváry J. (2004). Az óvodapedagógus személyisége. In: J. Jávorné Kolozsváry (Ed.) Az óvodapedagógus szerep kihívásai (pp. 39-58). Budapest: Trezor Kiadó.

Jenei A., Locsmándi A., \& Megyeri J. (2006). Együttnevelés kéttanáros pedagógiai modellben. In: M. Tamás (Ed.) Integráció és inklúzió: fejlesztő módszerek a közoktatásban (pp. 34-46.). Budapest: Trefort Kiadó. 
Kaga, Y., Bennett, J., \& Moss, P. (2010). Caring and learning together: A cross-national study on the integration of early childhood care and education within education. Paris: UNESCO.

Kernan, M. (2012). Parental involvement in early learning. Leiden: International Child Development Initiatives (ICDI) / The Hague: Bernard van Leer Foundation.

Korintus M., Villányi, G., Mátay K., \& Badics T. (2004). Gyermekeink gondozása és nevelése [Caring for our children]. Budapest: Corvinus Kiadó.

Ling Pan, M., \& Lopez, M. (2008). Preparing literature reviews: Qualitative and quantitative approaches. Glendale, CA: Pyrczak Publications.

Lightfoot-Rueda, T., \& Peach, R. L. (2015). Global perspectives on human capital in early childhood education: Reconceptualizing theory, policy, and practice. New York: Palgrave MacMillan.

McDowall Clark, R. (2016). Exploring the contexts for early learning: Challenging the school readiness agenda. Abingdon: Routledge.

McLafferty, I. (2004). Focus group interviews as a data collecting strategy. Journal of Advanced Nursing, 48(2), 187-194.

Miller, L., \& Hevey, D. (2012). Policy issues in the early years. London: Sage.

Ministry of Education and Science of Republic of Kazakhstan (MESRK) (2001; 2007a; 2008;

2009c; 2012) State Compulsory Education Standard in Early Childhood Education and Care.

Astana: MESRK.

Ministry of Education and Science of Republic of Kazakhstan (MESRK) (2007b). Program 'Children of Kazakhstan' for 2007-2011. Astana: MERSK.

Ministry of Education and Science of Republic of Kazakhstan (MESRK) (2007c). The Complex Program 'Karlygash'. Astana: MERSK.

Ministry of Education and Science of Republic of Kazakhstan (MESRK) (2009a). The Program 'ZerekBala' (3-5 years old). Astana: MERSK.

Ministry of Education and Science of Republic of Kazakhstan (MESRK) (2009b). Education Programme 'Algashky Kadam' (1-3 years old). Astana: MERSK.

Ministry of Education and Science of Republic of Kazakhstan (MESRK) (2010). The 'Balapan' Preschool Education Provision Programmes for 2010-2020. Astana: MESRK. Ministry of Education and Science of Republic of Kazakhstan (MESRK) (2013). Contemporary Models and Forms of Working with Parents in EY Settings: Methodical Recommendations. Astana: MESRK. 
Ministry of Education and Science of Republic of Kazakhstan (MESRK) (2014). Conceptual Principles of Early Childhood Development in Republic of Kazakhstan. Astana: MESRK

Retrieved from http://docslide.net/education/-55abf7f51a28abc44d8b4770.html Ministry of Education and Science of Republic of Kazakhstan (MESRK) (2015). Report on implementation of state education development programme of Republic of Kazakhstan for 2011/2020. Astana: MESRK.

Ministry of Education and Science of Republic of Kazakhstan (MESRK) (2016). National report on development of education system of the Republic of Kazakhstan. Astana: JCS Information Analytical Centre MESRK.

Mitchell, M., \& Egudo, M. (2003). A review of narrative methodology. Edinburgh, South Australia: Defence, Science and Technology Office, Australian Government Department of Defence.

Molnár, B., Pálfi, S., Szerepi, S., \& Nagy Varga, A., (2015). Kisgyermekkori nevelés Magyarországon (Early childhood education in Hungary). Educatio, 3, 121-128.

Moser, T., Melhuish, E., Petrogiannis, K., Pastori, G., Slot, P., \& Leseman, P. (2014). Initial framework for evaluating and monitoring ECEC quality and wellbeing. Working paper published online for eliciting stakeholder contributions. CARE: Curriculum \& Quality Analysis and Impact Review of European Early Childhood Education and Care, Utrecht University. Available at http://ecec-care.org/resources/publications/

Moss, P. (2017). Briefing on the OECD's international early learning study. Unpublished manuscript.

Murray, J. (2015) Early childhood pedagogies: spaces for young children to flourish. Early Child Development and Care, 185 (11-12), 1715-1732.

Nagy Varga, A., Molnár, B., Pálfi, S., \& Szerepi, S. (2015) Hungarian Perspectives on Early Years Workforce Development In: V. Campbell-Barr, \& J. Georgeson, International Perspectives on Early Years Worforce Development (pp. 109-121). Northwich: Critical Publishing Ltd.

Nazarbayev Intellectual Schools (NIS) Autonomous Educational Organisation (AEO) (2015). Code of ethics for conducting research in education. Astana: NISAEO [Online] Available at http://research.nis.edu.kz/wp-content/images/files/Research-Development-FrameworkAppendix-A-V-2.pdf Accessed 11.12.16.

Nutbrown, C. (2012). Foundations for quality: Final report. London: Department for Education. 
Nutbrown, C. Hannon, P., \& Morgan, A. (2005). Early literacy work with families: Policy, practice and research. London: Sage.

Organisation for Economic Cooperation and Development (OECD) (2017). Starting Strong V

- Transitions for Early Childhood Education and Care to Primary Education. Paris: OECD.

Ottesen, E. (2007). Teachers 'in the making': Building accounts of teaching. Teaching and Teacher Education, 23(5): 612-623.

Page, J. (2011). Do mothers want professional carers to love their babies? Journal of Early Childhood Research, 9(3), 310-323.

Pálfi, S. (2004). Nevelő-támogató vagy előkészítő-fejlesztő. In: J. Jávorné Kolozsváry (Ed.) Az óvodapedagógus szerep kihívásai (pp. 123-131). Budapest: Trezor Kiadó.

Pálfi S. (2006). A globalizáció hatása a Magyar óvodákra. In: Globalizációs ismeretek galenos alapitvány. Hajdúböszörmány: Debreceni Egyetem Gyermeknevelési és Felnőttképzési Kar.

Pálfi S. (2010). A Magyar óvodai projektpedagógia elméleti alapjai. Debrecen: Debrecen University Press.

Patton, M.Q. (2002). Qualitative Research and Evaluation Methods. Thousand Oaks: Sage Petriwskyj, A., Thorpe, K., \& Tayler, C. (2005). Trends in construction of transition to school in three western regions, 1990-2004. International Journal of Early Years Education, 13(1), $55-69$.

Pukánszky, B. (2005). A gyermekröl alkotott kép változásai az óvoda történetében. Educatio, 14(4), 703-15.

Read, J. (2015). Transformation and regulation: A century of continuity in nursery school and welfare policy rhetoric. Journal of Education Policy, 30(1), 39-61.

Rentzou, K. (2017). Using rating scales to evaluate quality early childhood education and care: Reliability issues. European Early Childhood Education Research Journal, 25(5), 667681.

Roberts-Holmes, G., \& Bradbury, A. (2016). Governance, accountability and the datafication of early years education in England. British Educational Research Journal, 42(4), 600-613.

Royston, S., \& Rodrigues, L. (2013). Breaking barriers: How to help children's centres reach disadvantaged families. London: The Children's Society.

Rozas, L.W., \& Klein, W.C. (2010). The value and purpose of the traditional qualitative literature review. Journal of Evidence Based Social Work, 7(5), 387-399. 
Sallai G. (2001). Az óvoda és a család kapcsolata. In: G. Villányi (Ed.) Óvodavezetők kézikönyve IX. (Pp.30-) OKKER.

Schneider, J., Avis, M., \& Leighton, P. (2007). Supporting children and families. London: Jessica Kingsley.

Social Mobility Commission (2016). State of the nation 2016: Social mobility in Great Britain. London: Open Government Licence. Retrieved from:

https://www.gov.uk/government/publications/state-of-the-nation-2016

Šteh, B., \& Kalin, J. (2011). Building partner cooperation between teachers and parents.

Center for Educational Policy Studies Journal, 1(4), 81-101.

Szilágyi, J., \& Szecsi T. (2005). A Hungarian preschool for the children, teachers, and families. Childhood Education, 81(5), 261-266.

Tagayeva, E.U. (2013). Children's speech development: Family and nursery interaction. Moscow: Booky-Vedi.

Taguma, M., Litjens, I., \& Makowiecki, K. (2012). Quality matters in early childhood education and care United Kingdom (England). Retrieved from:

http://www.oecd.org/education/school/50165861.pdf

Teszenyi, E., \& Hevey, D. (2015). Age group, location or pedagogue: factors affecting parental choice of kindergartens in Hungary. Early Child Development and Care, 185(11-12), 1961-1977.

Tonkova, U., \& Veretennikova, N. (2012). Contemporary models of interaction between early years settings and family. Issues and Perspectives of Education. Volume II of International Research Conference. Perm.

Török B. (2005). Óvodák és szülők [Kindergartens and parents]. Educatio, 4, 787-804. United Nations (2016). Sustainable Development Goals. Goal 4: Ensure inclusive and quality education for all and promote lifelong learning. Retrieved from:

http://www.un.org/sustainabledevelopment/education/

United Nations Educational, Scientific and Cultural Organization (UNESCO) (2011). World data on education, VII Ed 2010/11. Retrieved from:

http://www.ibe.unesco.org/sites/default/files/Kazakhstan.pdf

United Nations Educational, Scientific and Cultural Organization (UNESCO) (2016). Global education monitoring report: SDG 4. Retrieved from: http://en.unesco.org/gem-report/sdggoal-4

Vágó, I. (2002). Pre-school institutions, pre-school education in the new millennium. Retrieved from: http://ofi.hu/tudastar/ovodai-intezmenyrendszer 
Vincent, C., Braun, A., \& Ball, S.J. (2010). Local links, local knowledge: Choosing care settings and schools. British Educational Research Journal, 36(2), 279-298.

Walsham, G. (1993). Interpreting information systems in organizations. Wiley: Chichester. Watson, J. (2012). Starting well: Benchmarking early education across the world. London: EIU.

Whalley, M. (Ed.) (2007). Involving parents in their children's learning. London: Paul Chapman Publishing.

Wheeler, H., \& Connor, J. (2009). Parents, early years and learning. London: National Children's Bureau.

Whitbread, N. (1972). The evolution of the nursery-infant school. London: Routledge. Zhoumagozhina, R. (1973). From the history of early childhood development in country. Journal of Primary School, 12, 22-26.

Zvereva, O. (2016). Involvement of parents in educational process of the preschool educational organization as making interactions. Moscow. Retrieved from:

http://dovosp.ru/insertfiles/files/VAK/2016 05/2.pdf

\section{9 words}


Table 1: Characteristics of Research Team Members

\begin{tabular}{|l|l|l|l|l|l|l|l|l|}
\hline Country: & $\begin{array}{l}\text { Male / } \\
\text { female }\end{array}$ & Age & $\begin{array}{l}\text { ECEC } \\
\text { academic }\end{array}$ & $\begin{array}{l}\text { How } \\
\text { many } \\
\text { years as } \\
\text { an ECEC } \\
\text { academic? }\end{array}$ & $\begin{array}{l}\text { 3 key aspects } \\
\text { of current role } \\
\text { in a University }\end{array}$ & Parent? & $\begin{array}{l}\text { Experience } \\
\text { as an ECEC } \\
\text { practitioner? }\end{array}$ & $\begin{array}{l}\text { How many } \\
\text { years of } \\
\text { experience as } \\
\text { an ECEC } \\
\text { practitioner? }\end{array}$ \\
\hline $\begin{array}{l}\text { Researcher 1 } \\
\text { England }\end{array}$ & Female & 53 & Yes & 13 & $\begin{array}{l}\text { Administration } \\
\text { Teaching } \\
\text { Research }\end{array}$ & Yes & Yes & 20 \\
\hline $\begin{array}{l}\text { Researcher 2 } \\
\text { England }\end{array}$ & Female & 47 & Yes & 5 & $\begin{array}{l}\text { Teaching } \\
\text { Research } \\
\text { Writing }\end{array}$ & Yes & Yes & 11 \\
\hline $\begin{array}{l}\text { Researcher 3 } \\
\text { Hungary }\end{array}$ & Female & 50 & Yes & 9 & $\begin{array}{l}\text { Teaching } \\
\text { Research } \\
\text { Writing }\end{array}$ & Yes & Yes & 17 \\
\hline $\begin{array}{l}\text { Researcher 4 } \\
\text { Hungary }\end{array}$ & Male & 57 & Yes & 9 & $\begin{array}{l}\text { Teaching } \\
\text { Research } \\
\text { Writing }\end{array}$ & Yes & Yes & 8 \\
\hline $\begin{array}{l}\text { Researcher 5 } \\
\text { Kazakhstan }\end{array}$ & Female & 49 & Yes & 26 & $\begin{array}{l}\text { Administration } \\
\text { Teaching } \\
\text { Research }\end{array}$ & Yes & No & - \\
\hline $\begin{array}{l}\text { Researcher 6 } \\
\text { Kazakhstan }\end{array}$ & Female & 32 & Yes & 7 & $\begin{array}{l}\text { Administration, } \\
\text { Teaching } \\
\text { Research }\end{array}$ & No & Yes & 7 \\
\hline
\end{tabular}


Table 2: Focus Group Participants

\begin{tabular}{|c|c|c|c|c|c|}
\hline \multicolumn{3}{|c|}{ Participant Countries > } & UK & Hungary & Kazakhstan \\
\hline \multicolumn{3}{|c|}{ N = Focus Group participants } & 6 & 5 & 5 \\
\hline \multirow[t]{2}{*}{ Gender } & \multicolumn{2}{|c|}{ Female } & $66 \%$ & $60 \%$ & $100 \%$ \\
\hline & \multicolumn{2}{|c|}{ Male } & $33 \%$ & $40 \%$ & - \\
\hline \multicolumn{3}{|c|}{ Age range of participants (years) } & $44-53$ & $44-62$ & $51-60$ \\
\hline \multicolumn{3}{|c|}{ Mean age of participants (years) } & 51.3 & 50.2 & 55.8 \\
\hline \multicolumn{3}{|c|}{ Participants = ECEC academics } & $100 \%$ & $100 \%$ & $100 \%$ \\
\hline \multicolumn{3}{|c|}{$\begin{array}{l}\text { Range of years participants were } \\
\text { ECEC academics }\end{array}$} & $1-13$ & $2-20$ & $16-39$ \\
\hline \multicolumn{3}{|c|}{$\begin{array}{l}\text { Mean years participants were ECEC } \\
\text { academics }\end{array}$} & 4.3 & 13.2 & 25.2 \\
\hline \multirow{4}{*}{\multicolumn{2}{|c|}{$\begin{array}{l}\text { Participants' key } \\
\text { characteristics of } \\
\text { current roles as } \\
\text { ECEC academics }\end{array}$}} & Administration: & $83 \%$ & - & $80 \%$ \\
\hline & & Teaching: & $100 \%$ & $100 \%$ & $80 \%$ \\
\hline & & Research: & $100 \%$ & $100 \%$ & $100 \%$ \\
\hline & & Writing: & $17 \%$ & $100 \%$ & - \\
\hline \multicolumn{3}{|c|}{ Participants who were parents } & $100 \%$ & $100 \%$ & $40 \%$ \\
\hline \multicolumn{3}{|c|}{$\begin{array}{l}\text { Participants with experience as } \\
\text { ECEC practitioners }\end{array}$} & $83 \%$ & $20 \%$ & $60 \%$ \\
\hline \multicolumn{3}{|c|}{$\begin{array}{l}\mathrm{N}=\text { mean years participants were } \\
\text { ECEC practitioners, where } \\
\text { applicable }\end{array}$} & 13.6 & 20 & 13 \\
\hline
\end{tabular}


Table 3: Frequency of common themes in each country's sources

\begin{tabular}{|l|l|l|l|}
\hline \multirow{2}{*}{ Five common themes } & \multicolumn{3}{l|}{$\begin{array}{l}\text { Frequency of common themes in each } \\
\text { country's sources }\end{array}$} \\
\cline { 2 - 4 } & England & Hungary & Kazakhstan \\
\hline (i) Parental choice in ECEC provision & 12 & 6 & 5 \\
\hline $\begin{array}{l}\text { (ii) Power imbalances in parent-practitioner partnership } \\
\text { in ECEC provision }\end{array}$ & 6 & 3 & 9 \\
\hline (iii) School starting ages & 7 & 3 & 5 \\
\hline $\begin{array}{l}\text { (iv) Culture of parent-practitioner links in ECEC } \\
\text { provision }\end{array}$ & 7 & 4 & 7 \\
\hline $\begin{array}{l}\text { (v) The role of ECEC provision in preparing children for } \\
\text { formal schooling. }\end{array}$ & 6 & 2 & 5 \\
\hline
\end{tabular}

